Article

\title{
Native Seedling Colonization on Stockpiled Mine Soils Is Constrained by Site Conditions and Competition with Exotic Species
}

\author{
Kathy A. Baethke ${ }^{\circledR}$, Laura W. Ploughe *®D, Wendy C. Gardner and Lauchlan H. Fraser \\ Department of Natural Resource Science, Thompson Rivers University, Kamloops, BC V2C 0C8, Canada; \\ kathybaethke@shaw.ca (K.A.B.); wgardner@tru.ca (W.C.G.); lfraser@tru.ca (L.H.F.) \\ * Correspondence: lploughe@tru.ca
}

Received: 12 February 2020; Accepted: 15 April 2020; Published: 17 April 2020

check for updates

\begin{abstract}
Sites disturbed through mining practices can be challenging to restore with native vegetation, as the path of ecological succession is often unknown and hard to predict. We conducted an establishment study that explored restoration strategies to increase native vegetation on a newly formed stockpile of soil at New Gold's New Afton Mine in British Columbia, Canada. Establishment of native species in semi-arid grasslands is often constrained by seed and seedling microsite limitations, so treatments were imposed to assist in reducing these limitations. We established a fully factorial design with a native seed treatment (seeded and unseeded) and four soil preparations: raking, hydroseed slurry, a combination of raking and hydroseed slurry, and no preparation. Raking assisted in increasing total seedling establishment, regardless of whether the site was seeded or not. Raking and seeding increased the number of native seedlings and resulted in the greatest species richness, suggesting that native seedling establishment is primarily seed-limited, but that microclimate is also important for the establishment of some native seeds. We found that exotic species were able to capitalize on the disturbance and outcompeted the native species, but reducing seed-limitations by sowing more native seeds and increasing available microclimates by raking or tilling may increase native species' success at the establishment phase.
\end{abstract}

Keywords: colonization; competitor; disturbance; forb; grass; legume; microclimate; mine; native diversity; native seed; richness; ruderal; stress tolerator

\section{Introduction}

Global land-use change and industrialization have created degraded sites around the world that require remediation to re-establish important ecosystem services, such as native biodiversity, habitat, erosion control, and carbon sequestration. While mining provides important natural resources and economic growth, the activities associated with mining, including the building of infrastructure and the mining process itself, create heavily disturbed areas that can be particularly difficult to revegetate. Mining can reduce the availability of soil nutrients [1], disrupt soil microbial communities [2,3], increase soil compaction from the use of heavy equipment resulting in decreased water and root penetration [1], and increase the potential for invasion by exotic species [4,5]. Without intervention, natural succession on mine sites can be a slow process, and it can take between 50-100 years for vegetative cover to be adequately restored [6,7]. Restoration measures are often required at mine sites to manipulate the physical environment or biota in ways that accelerate plant establishment in an effort to reduce erosion by establishing vegetative cover quickly [8].

Historically, mines have used agronomic seed mixes in restoration because of their ability to colonize quickly, reducing erosion and making the area aesthetically pleasing [9,10]. However, 
agronomic species can become dominant monocultures, reducing native species' abundance and diversity within the site and the surrounding landscape [11]. More recently, there has been a desire to move away from planting agronomic species in favor of planting native species to increase native diversity, restore sites to a more natural state and create ecosystems that are self-sustainable [12]. Seeding with native species from nearby remnants could increase the emergence, survival, and establishment of a variety of native seedlings, which are expected to establish reproducing populations that will assemble into a community similar to the natural landscape [13-15].

Seedling emergence and colonization is a critical stage in successfully restoring ecosystems with native species, because this stage funnels individuals into the system that may not have appeared without intervention [13]. However, restored ecosystems often have lower plant species richness and diversity compared to sites that have been restored with spontaneous revegetation. Low species diversity is often associated with reduced seedling emergence rates, which may be the result of seed limitation or seedling microsite limitation within the site, and can greatly affect germination and seedling survival [13,16-18]. Successional communities developing on these degraded sites often become dominated by exotic species $[19,20]$, which may contribute to the low diversity associated with these sites and may inhibit native plant colonization, depending on their ability to monopolize resources and inhibit recruitment $[19,21]$. Further, restoration of semi-arid grasslands presents a unique set of challenges, as it is often constrained by environmental factors, such as erosion, soil compaction, and climate, as well as economic limitations [8,22]. Additionally, the lack or low availability of and/or the high cost of native seeds can make native restoration goals difficult to obtain in large-scale mine restorations [23]. Together, these factors make finding techniques to ensure successful restoration of native species challenging.

Along with seeding with native species to help promote the establishment of native populations, different site preparation techniques have been used in grassland restoration to increase colonization of desirable species, increase the native seed bank, and reduce microclimate constraints [13,24,25]. Here, we explore two site preparation techniques along with planting native seeds to increase seedling colonization, tilling and hydroseeding. Tilling can increase soil porosity, allowing for better root penetration and access to water and nutrients; increase water infiltration rates; and increase surface heterogeneity, creating microsites for seedling establishment [26-28]. Low-disturbance tilling like raking can reduce soil compaction [29] and promote native seedling establishment by roughening the soil surface and creating microclimates [9,26,30-33]. While low-disturbance tilling can promote native seedling establishment, whether tilling decreases or increases invasion by exotics remains unclear $[26,27,34,35]$.

Another common site preparation used in restoration of semi-arid degraded sites like mines [12,36] or road slopes $[37,38]$ is hydroseeding. Hydroseeding involves spraying binder, mulch, wood or paper fiber, and seeds using water over large and/or inaccessible areas [25]. Hydroseeding is often used for revegetation in an attempt to reduce erosion and create microclimates by altering the amount of evapotranspiration and soil moisture availability [39]. The use of hydroseeding in semi-arid and disturbed environments has produced conflicting results, with some finding hydroseeding with native species resulted in poor seedling establishment $[38,40]$ and others successfully revegetating road banks with hydroseeded native species [27,41]. The components of the hydroseed mixture may mimic the effects small amounts of litter have on microclimates and increase soil nutrient availability [25,38,40,42,43]. The low amounts of litter provided by hydroseeding may improve seedling growth when competitors are present, which may have an indirect positive effect on seedling emergence or growth [44].

Little is known about how implementing these site restoration techniques, specifically hydroseeding and raking, will affect native seedling establishment in heavily disturbed mine sites. The goal of this research was to explore ecological restoration methods that help reduce seed and seedling microsite limitations in an effort to maximize native plant diversity. Sites were established on stockpiled mine soils. The stockpile used in this experiment was newly formed (less than 2 years old) 
and consisted of a mixture of soils from $\mathrm{O}$ to $\mathrm{C}$ horizons. We established a fully factorial experiment that incorporated native seed (seeded or unseeded) and site preparation (none, raking, hydroslurry, and raking and hydroslurry) treatments. We use the phrase hydroslurry instead of hydroseeding because some of the treatments included the native seed mix while others did not; thus, hydroslurry indicates a mixture of water, mulch, and other binding materials that are typically present in hydroseed mixtures. We explore four main questions: (1) does seeding with native species increase native seedling establishment; (2) are site preparations, hydroseeding and raking, necessary to aid in the establishment of native seedlings; and (3) how do these treatments impact the diversity of colonized species?

\section{Materials and Methods}

\subsection{Site Description}

The study took place at New Gold's New Afton Mine west of Kamloops, British Columbia, Canada (50³8'54.92" N 120²9'59.67" W, elevation 775 m). The New Afton Mine is an underground, working copper-gold mine situated on a historical open pit. The mine is located in the Ponderosa Pine and Interior Douglas-fir biogeoclimatic zone, and the surrounding grasslands are a northern extension of the Pacific Northwest Bunchgrass grasslands, also known as Middle Grasslands [45]. The soils associated with the Middle Grasslands in this region are characterized as silt loam to silty clay loam McQueen Orthic Dark Brown Chernozem [46-48]. The Middle Grasslands are characterized by the absence of the characteristic shrub species, Artemisia tridentata, of the Lower Grasslands and of the taller forbs and broad-leaved shrubs of the Upper Grasslands. The climax community in the Middle Grasslands is dominated by Pseudoroegneria spicata and Poa secunda [46-48]. This area has a short, warm summer season (May-September), with average temperatures ranging from $8{ }^{\circ} \mathrm{C}$ to $29^{\circ} \mathrm{C}$ respectively. Winter mean annual temperatures range from $-6{ }^{\circ} \mathrm{C}$ to $5.6{ }^{\circ} \mathrm{C}$. The mean annual precipitation is $278 \mathrm{~mm}$, with $81 \%$ of the moisture coming as rainfall and $19 \%$ coming as snowfall [45].

\subsection{Seed Collection}

Plant species selected for sowing were chosen based on their common presence within the interior grasslands of British Columbia, their cultural importance to indigenous people of the local First Nations bands (TK'emlups and Skeetchestn) and our ability to obtain seeds in sufficient quantity (Table 1). Seeds were either handpicked or sourced from local seed companies. Seeds purchased from Pick Seed and Quality Seeds were advertised as having seed viability of greater than $90 \%$. Seeds collected in the field were obtained from several populations near the site in the fall of 2012, with the exception of Mentzelia laevicaulis and Oxytropis campestris. Both M. laevicaulis and O. campestris were collected from a single population at the New Afton Mine site and Teck Resources' Highland Valley Copper Mine site, respectively. After collection, all seeds were allowed to air dry in a paper bag; dried seeds were sealed in plastic ziplock bags and stored in a chest freezer at $-18^{\circ} \mathrm{C}$. To estimate seed viability, twenty seeds of each species were placed on moist sand in petri dishes in the greenhouse and were observed for germination over a period of 26 days [49]. Germination rates were estimated to be $>90 \%$ for grass species and $>80 \%$ for most forb species (Table 1 ). Seed packets were prepared for fall planting and included enough seeds to seed at a rate of $1200 \mathrm{seeds} / \mathrm{m}^{2}$ [50]. Sand was used as a carrying agent in each of the envelopes, and 12 forb and 12 graminoid native species were added at 200 seeds/plot for each species. 
Table 1. List of seeded species, including plant functional group, where seeds were purchased (Pickseed, Vancouver, BC or Quality Seeds West, Abbotsford, BC) or (when hand-picked) where the seed populations were located, and the First Nations Secwepemc names when known. An asterisk next to the species name indicates seeds that had germination rates lower than $80 \%$.

\begin{tabular}{|c|c|c|c|c|}
\hline Species & Common Name & Functional Group & Source & $\begin{array}{c}\text { First Nations } \\
\text { Secwepemc Name }\end{array}$ \\
\hline Achnatherum hymenoides & Indian rice grass & Grass & Pickseed & \\
\hline Elymus glaucus & Blue wildrye & Grass & Pickseed & \\
\hline Elymus trachycaulus & Slender wheatgrass & Grass & Pickseed & \\
\hline Festuca campestris & Rough fescue & Grass & Pickseed & \\
\hline Festuca idahoensis & Idaho fescue & Grass & Pickseed & \\
\hline Festuca saximontana & Rocky mountain fescue & Grass & Pickseed & \\
\hline Hespirostipa comata & Needle-and-thread grass & Grass & Pickseed & \\
\hline Koeleria macrantha & June grass & Grass & Pickseed & \\
\hline Poa juncifolia & Alkali bluegrass & Grass & Pickseed & \\
\hline Poa secunda & Sandberg bluegrass & Grass & Pickseed & \\
\hline Pseudoroegneria spicata & Blue bunch wheatgrass & Grass & Pickseed & \\
\hline Sporobolus cryptandrus & Sand dropseed & Grass & Pickseed & \\
\hline Achillea millifolium & Yarrow & Forb & Pickseed & qets'uye7ellp (W) \\
\hline Antennaria rosea/umbrinella & Pussytoes (rose/umber) & Forb & Lac du Bois, Kamloops, BC & \\
\hline * Astragalus purshii & Woollypod milkvetch & Forb & Lac du Bois, Kamloops, BC & \\
\hline Balsamorhiza sagittata & Arrow-leaved balsamroot & Forb & Pickseed & Ts'elqenupye7 \\
\hline Campanula rotundifolia & Harebell & Forb & Lac du Bois, Kamloops, BC & \\
\hline Delphinium nuttallianum & Larkspur & Forb & Quality Seeds & \\
\hline Erigeron compositus & Cutleaf fleabane & Forb & Lac du Bois, Kamloops, BC & \\
\hline Erigeron filifolius & Threadleaf fleabane & Forb & Lac du Bois, Kamloops, BC & \\
\hline Fritillaria pudica & Yellow bells & Forb & Quality Seeds West & \\
\hline Gaillardia aristata & Brown-eyed susan & Forb & Pickseed & sqlelten re ckwtut'stens \\
\hline Mentzelia laevicaulis & Blazing star & Forb & New Afton Mine, Kamloops, BC & \\
\hline * Oxytropis campestris & Field locoweed & Forb & Highland Valley Copper, Logan Lake, BC & \\
\hline
\end{tabular}




\subsection{Experimental Design}

A stockpile located north of the tailing pond at New Afton Mine was levelled, and a grid of 80 bare soil plots was established in October 2012. The stockpile was approximately two years old at the time of the experiment and included a mixture of soils from the $\mathrm{O}$ to $\mathrm{C}$ horizons. Each plot measured two $\mathrm{m}^{2}$ with a half-meter buffer between each plot. Eight treatments were applied to each plot and replicated 10 times $(n=10)$. Four soil preparation treatments-(1) raking, (2) hydroslurry, (3) hydroslurry and raking, and (4) no site preparation-and two seeding treatments-seeded and not seeded-were established in a fully factorial design. Raking was applied using a hand rake with ten 6-cm tines. The hydroslurry treatment was created using a formula used by the mine to hydroseed embankments. The hydroslurry mixture included two bags of ecofibre premium wood fibre mulch $(22.68 \mathrm{~kg}), 2.25 \mathrm{~L}$ premium super tackifier, $18.1 \mathrm{~kg}$ jet spray fibre mulch with poly fibre. This mixture and water was added to a large hydroseeder drum to fill the drum to 550 gallons and was thoroughly mixed with mixing paddles.

Seeding took place in November 2012, when temperatures were low enough $\left(<10^{\circ} \mathrm{C}\right)$ to ensure early germination would not occur [20]. Seeds designated to the hydroslurry treatment were mixed into the hydroslurry by filling $2 \times 12 \mathrm{~L}$ buckets and then adding half of the seed mixture into each bucket. To ensure even mixing of the seeds in the slurry, a stick was used to stir the seed mix into the slurry. Packets without seeds contained only sand and were mixed into the hyrdroslurry in a similar fashion to the seeded packets. The hydroslurry mixtures were spread over the plots by pouring the two buckets evenly over each plot. Seeds that did not receive the hydroslurry treatment were hand-broadcast onto treatment plots, including sand-only packets. Hand-seeding was conducted by the same two people to reduce bias. All unseeded plots received the hydroslurry first to ensure no contamination occurred between unseeded and seeded treatment sites.

In the spring of 2013, plots were watered with $4 \mathrm{~mm}$ of water twice a week beginning in May using watering cans with disperser spouts. Watering continued until June rains began and then plots were only watered on watering days when there was no precipitation. Plots were watered until the water pooled on the soil surface. This moisture was allowed to seep through the soil before the remaining water was added.

Vegetation surveys were conducted in July of 2013 using a $1 \mathrm{~m}^{2}$ grid placed in the center of each treatment plot, and individuals within the grid were counted and recorded by species. Richness (S) was considered the number of different species within each plot. The Shannon-Weaver diversity index $\left(\mathrm{H}^{\prime}\right)$ was calculated using the equation below, where $\mathrm{p}_{\mathrm{i}}$ is the proportion of individuals of each species divided by the total number of individuals that germinated. Evenness was calculated using Pielou's evenness (J), where $\mathrm{J}=\mathrm{H}^{\prime} / \log (\mathrm{S})[51]$.

$$
\text { Shannon-Weaver index }=\mathrm{H}^{\prime}=\sum_{\mathrm{i}}^{\mathrm{S}} \mathrm{p}_{\mathrm{i}} \ln \left(\mathrm{p}_{\mathrm{i}}\right)
$$

Seedlings were classified as exotic or native based on their status in the Global Invasive Species Database [52] and whether they were seeded or not (Table 2), and the percentage of each of the four classifications were calculated based upon the total seedlings established in each plot. Seedlings were also classified using Grime's C-S-R theory, using current literature to describe the plant history traits of the seedlings that were established [53,54]. While this classification has been criticized as an oversimplification of communities, the C-S-R theory can be useful for understanding the type of succession occurring [54] and would allow us to gain a general understanding of how our treatments could potentially affect succession. 
Table 2. Species that established across sites that are categorized by: plant functional type, native, or exotic status, whether the species was seeded or not, and C-S-R category. The main indicators for the CSR classifications were: Competitors = perennials, tall, large leaf area, found in high resource locations; Ruderals = annuals; Stress-tolerators $=$ perennials, long-lived, carbon-based defense mechanisms, storage organs.

\begin{tabular}{|c|c|c|c|c|c|}
\hline Species & Common Name & Plant Functional Type & Native/Exotic & Seeded & CSR \\
\hline Artemisia frigida & Praire sagewort & Shrub & Native & $\mathrm{N}$ & $\mathrm{S}$ \\
\hline Astragalus tenellus & Pulse milk vetch & Legume & Native & $\mathrm{N}$ & $\mathrm{S}$ \\
\hline Artemisia tridentata & Big sagebrush & Shrub & Native & $\mathrm{N}$ & $\mathrm{s}$ \\
\hline Lotus denticulatus & Riverbar bird's-foot trefoil & Legume & Native & $\mathrm{N}$ & $\mathrm{S}$ \\
\hline Myosotis spp. & forget-me-not & Forb & Native & $\mathrm{N}$ & $\mathrm{s}$ \\
\hline Poa compressa & Canada bluegrass & Grass & Native & $\mathrm{N}$ & $\mathrm{C}$ \\
\hline Rumex acetosella & Common sheep sorrel & Forb & Native & $\mathrm{N}$ & $\mathrm{C}$ \\
\hline Thlaspi arvense & Field pennycress & Forb & Native & $\mathrm{N}$ & $\mathrm{R}$ \\
\hline Achillea millefolium & Yarrow & Forb & Native & $\mathrm{Y}$ & $\mathrm{R}$ \\
\hline Balsamorhiza sagittata & Arrowleaf & Forb & Native & $\mathrm{Y}$ & $\mathrm{S}$ \\
\hline Erigeron filifolius & Threadleaf fleabane & Forb & Native & Y & $\mathrm{s}$ \\
\hline Elymus glaucus & Wild rye & Grass & Native & $\mathrm{Y}$ & $\mathrm{C}$ \\
\hline Elymus trachycaulus & Slender wheatgrass & Grass & Native & Y & $\mathrm{R}$ \\
\hline Festuca spp. & & Grass & Native & Y & $\mathrm{s}$ \\
\hline Fritillaria pudica & Yellow fritillary & Forb & Native & $\mathrm{Y}$ & $\mathrm{S}$ \\
\hline Gaillardia aristata & Blanketflower & Forb & Native & $\mathrm{Y}$ & $\mathrm{S}$ \\
\hline Mentzelia laevicaulis & Smoothstem blazingstar & Forb & Native & Y & $\mathrm{S}$ \\
\hline Poa sandbergii & Sandberg bluegrass & Grass & Native & Y & $\mathrm{R}$ \\
\hline Pseudoroegneria spicata & Bluebunch wheatgrass & Grass & Native & Y & $\mathrm{s}$ \\
\hline Sporobolus cryptandrus & Sand dropseed & Grass & Native & Y & $\mathrm{S}$ \\
\hline Agropyron cristatum & Crested Wheatgrass & Grass & Exotic & $\mathrm{N}$ & $\mathrm{C}$ \\
\hline Berteroa incana & Hoary alyssum & Forb & Exotic & $\mathrm{N}$ & $\mathrm{S}$ \\
\hline Bromus squarrosus & Corn brome & Grass & Exotic & $\mathrm{N}$ & $\mathrm{C}$ \\
\hline Bromus tectorum & Cheatgrass & Grass & Exotic & $\mathrm{N}$ & $\mathrm{R}$ \\
\hline Chenopodium album & Lambsquarters & Forb & Exotic & $\mathrm{N}$ & $\mathrm{R}$ \\
\hline Camelina microcarpa & Littlepd false flax & Forb & Exotic & $\mathrm{N}$ & $\mathrm{C}$ \\
\hline Centaurea stoebe & Spotted knapweed & Forb & Exotic & $\mathrm{N}$ & $\mathrm{C}$ \\
\hline Descurainia sophia & Herb sophia & Forb & Exotic & $\mathrm{N}$ & $\mathrm{R}$ \\
\hline Elymus repens & Quackgrass & Grass & Exotic & $\mathrm{N}$ & $\mathrm{C}$ \\
\hline Kochia scoparia & Kochia & Forb & Exotic & $\mathrm{N}$ & $\mathrm{R}$ \\
\hline Latuca serriola & Prickly lettus & Forb & Exotic & $\mathrm{N}$ & $\mathrm{R}$ \\
\hline Melilotus alba & Sweetclover & Legume & Exotic & $\mathrm{N}$ & $\mathrm{C}$ \\
\hline Medicago lupulina & Black medick & Forb & Exotic & $\mathrm{N}$ & $\mathrm{s}$ \\
\hline Polygonum aviculare & Oval-leaf knotweed & Forb & Exotic & $\mathrm{N}$ & $\mathrm{C}$ \\
\hline Poa pratensis & Kentucky bluegrass & Grass & Exotic & $\mathrm{N}$ & $\mathrm{R}$ \\
\hline Sisymbrium loeselii & Small tumbleweed mustard & Forb & Exotic & $\mathrm{N}$ & $\mathrm{C}$ \\
\hline Salsola tragus & Prickly Russian thistle & Forb & Exotic & $\mathrm{N}$ & $\mathrm{S}$ \\
\hline Taraxacum officinale & Common dandelion & Forb & Exotic & $\mathrm{N}$ & $\mathrm{C}$ \\
\hline Triticum spp. & Wheat & Grass & Exotic & $\mathrm{N}$ & $\mathrm{C}$ \\
\hline
\end{tabular}




\subsection{Data Analysis}

Data were analyzed using mixed-model of analysis of variance in $\mathrm{R}$ version 3.61 (R Foundation for Statistical Computing, Vienna, Austria) using the 'lmer' function from the package "Ime4" [55]. All models included block as a random variable, and degrees of freedom were calculated using the Kenward-Roger method. Continuous variables were transformed when needed to fulfill model assumptions. Models exploring the effects of site preparation (hydroslurry and/or raking or no preparation), seed treatments (seeded or unseeded), and their interaction on seedling establishment and diversity metrics were calculated using the total number of individual seedlings per $\mathrm{m}^{2}$. Models exploring seedling composition based on plant functional groups (forb, grass, or legume), C-S-R category and native status (exotic or native) used the percent relative to the total number of individuals established per $\mathrm{m}^{2}$. Tukey HSD post-hoc analyses were performed on all models using the "emmeans" package to generate estimated marginal means (EMM; [56]). We also used a permutational multivariate analysis of variance (PERMANOVA) using Bray-Curtis similarity to assess community-level divergence between treatments based on the number of individuals per $\mathrm{m}^{2}$ using the 'adonis' function in the "vegan" package in R [51,55]. We used a Principal Coordinates Analysis to visualize the dissimilarity matrix. A post-hoc similarity percentage (SIMPER) analysis was performed to determine which species contributed most to differences among preparation treatments using the 'simper' function in the "vegan" package in R [55].

\section{Results}

\subsection{Total Seedling Establishment}

The total number of individuals per $\mathrm{m}^{2}$ varied depending on the site preparation treatment used $\left(\mathrm{F}_{3,63.2}=11.64, p<0.0001\right)$. Specifically, both raking treatments, raking alone and raking + hydroslurry, increased the number of seedlings that colonized the site compared to no preparation $(p<0.05$, Tukey HSD, Figure 1a). Seeding did not significantly affect the number of seedlings that colonized the sites. While total seedling establishment was not impacted by seeding with native species, seeding and raking or raking + hydroseeding increased the establishment of native species $\left(\mathrm{F}_{3,62.1}=4.79, p<0.01\right.$; Figure 1b), although most seedlings that established were exotic species.
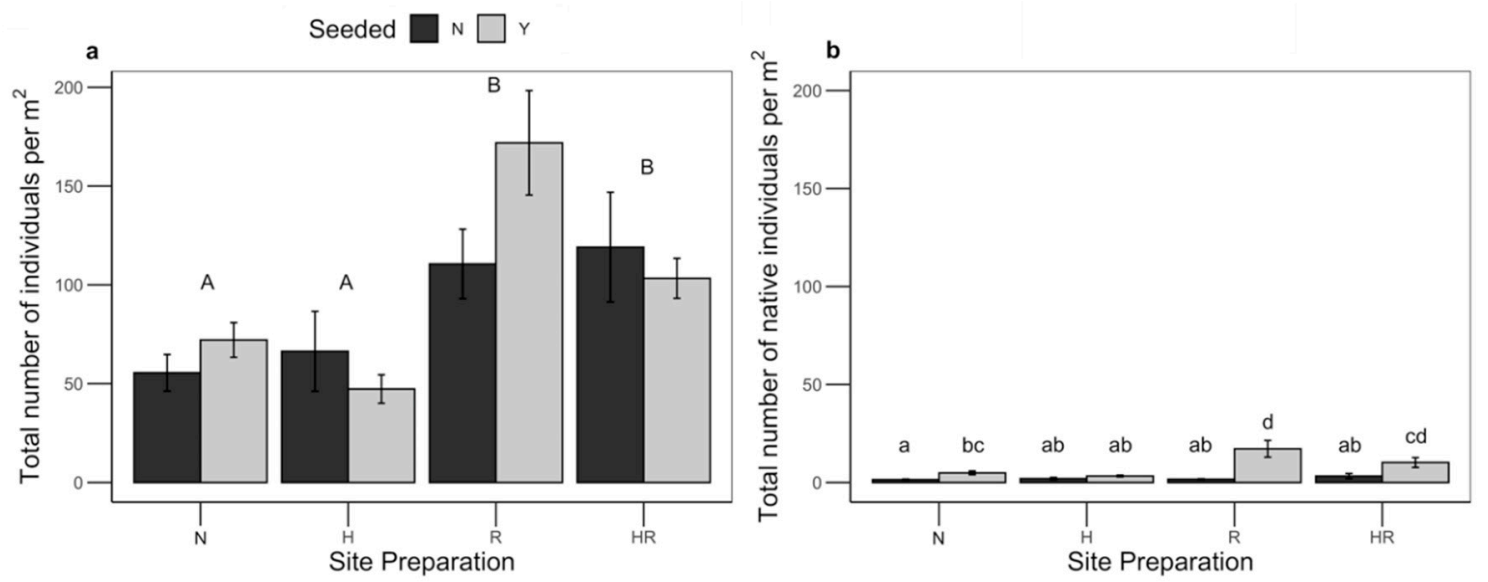

Figure 1. Mean (a) total seedling establishment $( \pm S E, n=10)$ and $(\mathbf{b})$ native seedling establishment based upon site preparation ( $\mathrm{N}$-no preparation, $\mathrm{H}$-hydroslurry, and $\mathrm{R}$-raking treatments and seed treatments (No-black and Yes-grey). Uppercase letters represent significant differences between site preparation treatments alone, and lower case letters represent differences found between the interaction of site preparation and seed treatments (Tukey HSD, $p<0.05$ ). 


\subsection{Plant Community Responses}

Richness (S) increased as a result of seeding $\left(\mathrm{F}_{1,62.9}=32.45, p<0.0001\right)$, and there was an interactive effect between the site preparation and seeding treatments $\left(\mathrm{F}_{3,62.8}=2.99, p=0.04\right)$. Post-hoc analysis revealed that the combination of seeding and raking alone likely results in greater richness compared to the no-preparation treatment $(p<0.05$, Tukey HSD, Figure 2a). Evenness (J) was impacted by the site preparation used $\left(\mathrm{F}_{3,63.2}=3.31, p=0.026\right)$, where raking alone decreased evenness and hydroslurry alone increased evenness, whether the sites were seeded or not $(p<0.05$, Tukey HSD, Figure $2 \mathrm{~b})$. The seeding treatment did not affect evenness. Diversity $(\mathrm{H})$ increased as a result of seeding $\left(\mathrm{F}_{11,9.2}=12.28\right.$, $p<0.01$; Figure 2c).

a

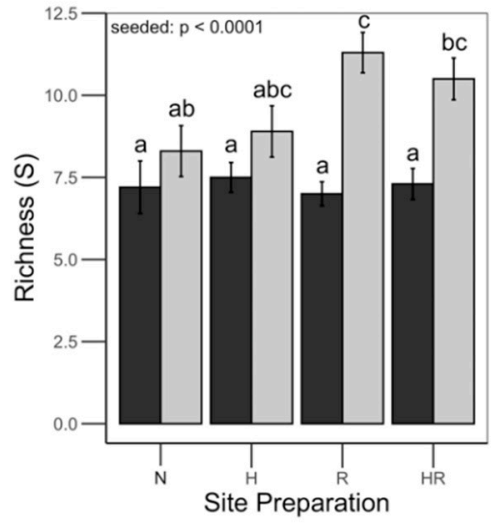

b

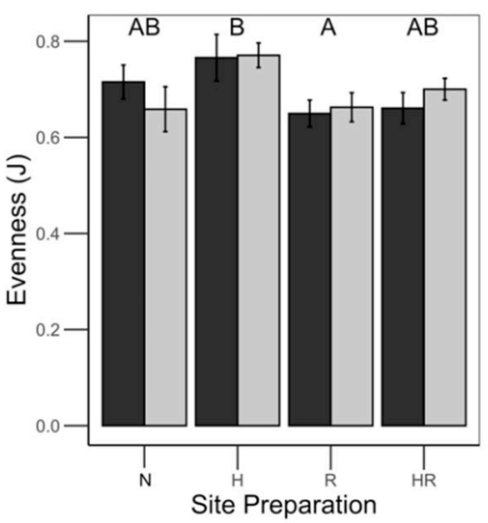

C

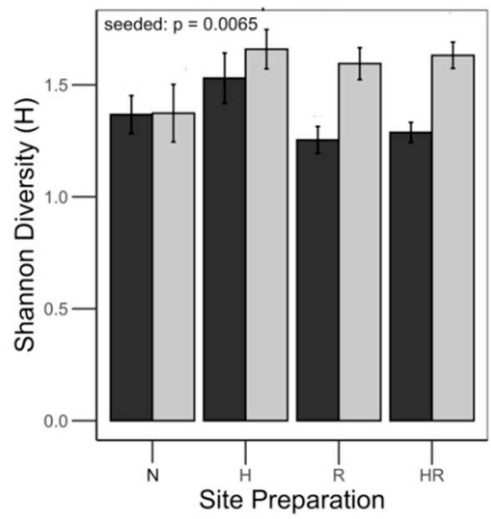

Figure 2. Mean (a) richness (S), (b) evenness (J), and (c) Shannon diversity $(H ; \pm S E, n=10)$ according to site preparation ( $\mathrm{N}$-no preparation, $\mathrm{H}$-hydroslurry, and $\mathrm{R}$-raking) and seeded (No-black and Yes-gray) treatments. Lower-case letters represent differences found between the interaction of site preparation and seed treatments, and upper-case letters indicate differences between site preparation treatments (Tukey HSD, $p<0.05$ ). Seeded treatment resulted in significant differences when indicated (alpha $<0.05)$.

The PERMANOVA revealed community divergence was influenced by the site preparation treatments $(p<0.0001$; Figure $\mathrm{S} 1)$. The species driving the divergences $(>5 \%)$ between site preparation treatments were Kochia scoparia, Salsola tragus, Sisymbrium loeselii, and Melilotus alba (Table S1). These species are all exotic forbs, with the exception of M. alba, which is an exotic legume. As a result of the low colonization rates of native species, we were unable to determine which native species contributed to the divergence between communities. However, the native species that colonized the site at the highest numbers appeared to benefit from raking alone, except $B$. sagittata, which performed the best when hydroseeding and raking were both implemented (Table 3).

Table 3. Mean number of the native species that colonized the plots $\left(2 \mathrm{~m}^{2}\right)$ in the highest numbers ( $>1$ individual); \pm SE) according to site preparation. Each of these species was seeded at a rate of 200 seeds/plot.

\begin{tabular}{ccccccc}
\hline Preparation & $\begin{array}{c}\text { Achillea } \\
\text { millefolium }\end{array}$ & $\begin{array}{c}\text { Balsamorhiza } \\
\text { sagittata }\end{array}$ & $\begin{array}{c}\text { Elymus } \\
\text { trachycaulus }\end{array}$ & Festuca spp. & $\begin{array}{c}\text { Gaillardia } \\
\text { aristata }\end{array}$ & $\begin{array}{c}\text { Pseudoroegneria } \\
\text { spicata }\end{array}$ \\
\hline None & $1.5(0.5)$ & $0.1(0.1)$ & 0 & $0.3(0.2)$ & $1.1(0.2)$ & 0 \\
Hydroseed & 0 & $0.3(0.2)$ & 0 & $0.2(0.2)$ & $1.1(0.3)$ & 0 \\
Hydroseed + Rake & $0.3(0.2)$ & $2.7(0.9)$ & $0.1(0.1)$ & $0.9(0.4$ & $3.6(1.5)$ & $1(0.5)$ \\
Rake & $2.9(0.7)$ & $0.5(0.4)$ & $1.4(.5)$ & $1(0.6)$ & $4.7(1.2)$ & $3.4(1.3)$ \\
\hline
\end{tabular}

\subsection{Exotic vs. Native Species}

Most of the seedlings ( $>88 \%$ ) that became established were species that were exotic species. These exotic species were almost exclusively exotic, with only 19 total native individuals of six different 
species becoming established across sites (Table 3). Seeding reduced the percentage of exotic seedlings that became established $\left(\mathrm{F}_{1,63.12}=33.27, p<0.0001\right.$; Figure 3a) and increased the percentage of native species $\left(F_{1,63.2}=63.84, p<0.0001\right.$; Figure $\left.3 b\right)$ from less than $2 \%$ to slightly over $7 \%$. Site preparation was not found to have an effect on the proportion of exotic or native species.
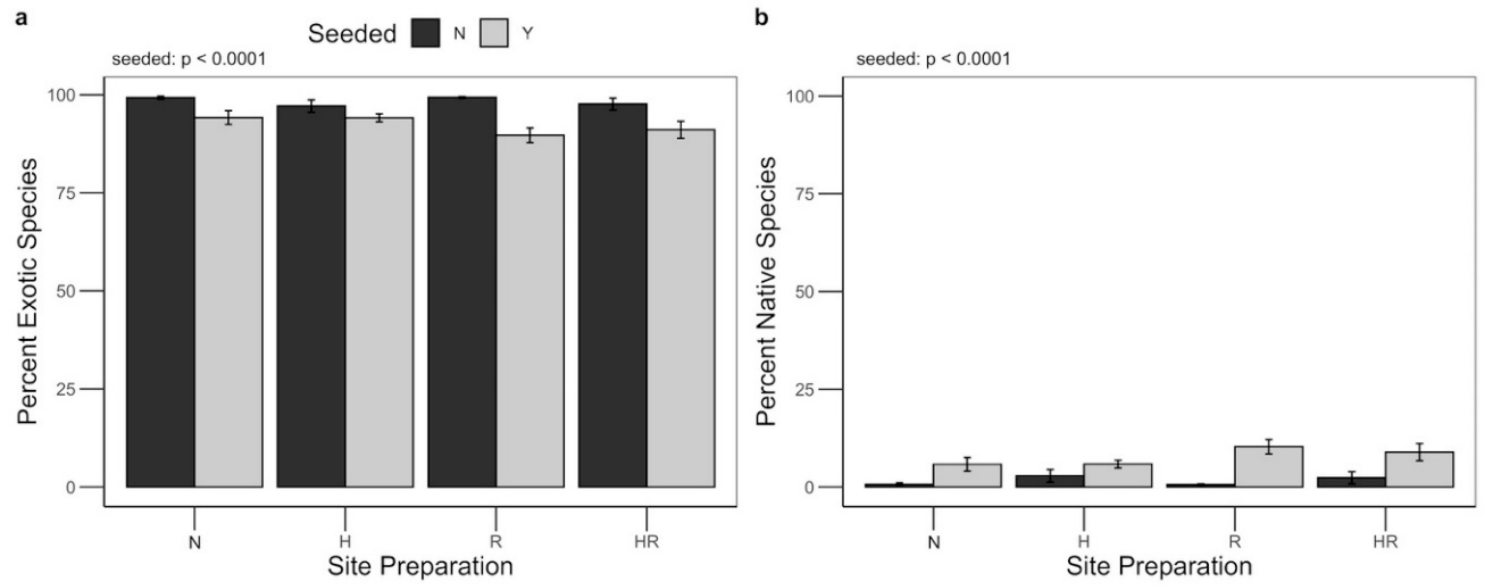

Figure 3. Mean percent (a) exotic and $(\mathbf{b})$ native seedlings $( \pm S E, n=10)$ according to site preparation (N-no preparation, $\mathrm{H}$-hydroslurry, and R—raking) and seeded (No-black and Yes—gray) treatments.

Seeded treatment resulted in significant differences $(p<0.0001)$.

\subsection{Life History Traits}

\subsubsection{Plant Functional Groups}

As a result of the small proportion of native species that established, models were run only on the total percentage of plant functional types' (forb, legume, and grass) colonization, regardless of native or exotic status (See Figure 3). Forb seedlings dominated all of the sites, with a mean percentage of forb seedlings being $86.6 \pm 1.1 \%$ across sites. Of the forb seedlings that colonized, only $3.8 \pm 0.5 \%$ were native forbs with the remainder being exotic species $(96.2 \pm 0.5 \%)$. We found that overall forb colonization was impacted by site preparation $\left(\mathrm{F}_{3,63.1}=9.08, p<0.0001\right.$; Figure $\left.4 \mathrm{a}\right)$, where the hydroslurry treatment decreased the proportion of forb seedling establishment (Tukey HSD, $p<0.05$ ).
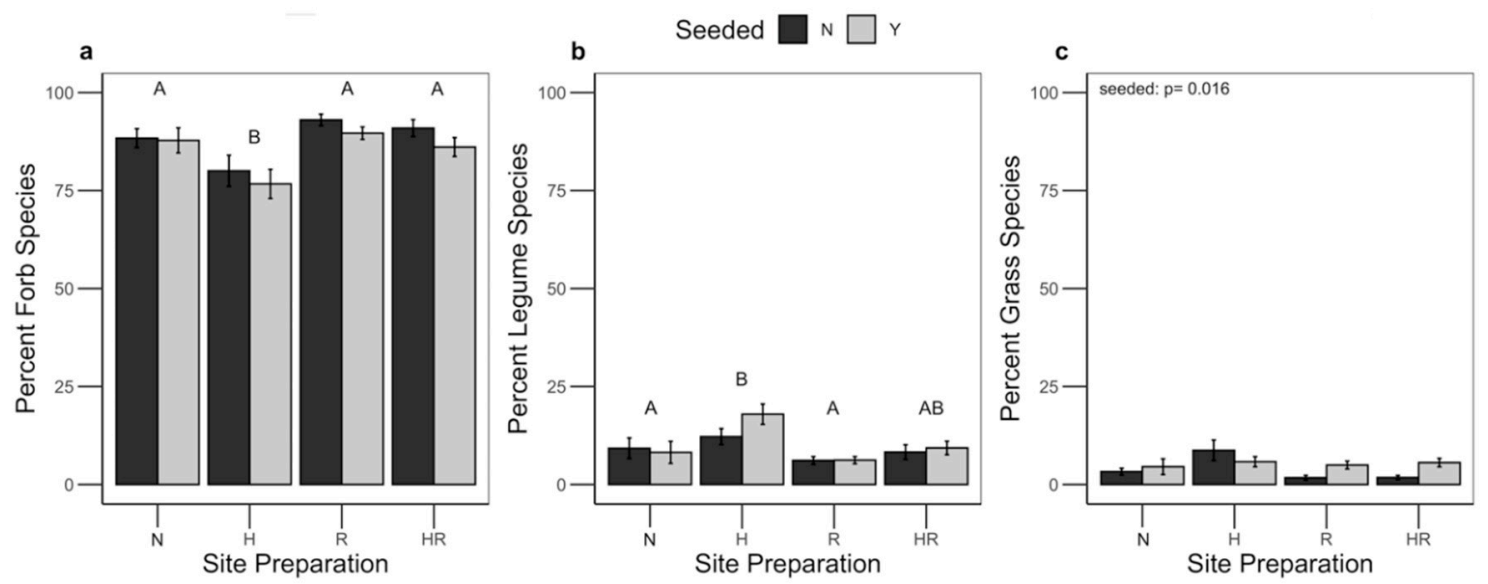

Figure 4. Mean percent (a) forb, (b) legume, and (c) grass seedling establishment $( \pm \mathrm{SE}, \mathrm{n}=10)$ according to site preparation ( $\mathrm{N}$-no preparation, $\mathrm{H}$-hydroslurry, and $\mathrm{R}$-raking) and seeded (No-black and Yes-gray) treatments. Upper-case letters indicate differences between site preparation treatments (Tukey HSD, $p<0.05)$. Seeded treatment resulted in significant differences when indicated (alpha $<0.05)$. 
Legumes were the next most abundant seedlings to colonize the sites, at $8.7 \pm 0.8 \%$ across all treatments. Again, most of the legumes that established were exotic species comprising $88.3 \pm 3.4 \%$ of the legume species that colonized the sites compared to native legume species $(1.7 \pm 0.8 \%)$. Site preparation affected the percentage of legume seedlings that became established $\left(\mathrm{F}_{2,63.1}=6.57, p<0.001\right.$; Figure $4 \mathrm{~b}$ ). The hydroslurry-only treatment increased the percentage of legume seedling colonization compared to no preparation and raking only treatment (Tukey HSD, $p<0.05$ ).

Only a small portion of grasses colonized the sites with a mean percent of grasses that became established across all sites being $4.5 \pm 0.5 \%$. Of the grass seedlings that became established, $65.4 \pm 4.7 \%$ were exotic and $19.6 \pm 3.7 \%$ were native species. Seeding increased the percentage of grass seedlings that became established $\left(\mathrm{F}_{3,63.1}=6.08, p=0.016\right.$; Figure $\left.4 \mathrm{c}\right)$, and site preparation had no effect on grass seedling establishment.

\subsubsection{Plant Adaptive Strategies: Grime's CSR}

Competitor seedling establishment was impacted by the site preparation that was used, whereas ruderal and stress tolerator species were not impacted by any treatment implemented $\left(\mathrm{F}_{3,63}, p=0.022\right)$. Seeding did not influence the colonization of competitor, stress tolerator, or ruderal seedlings. Post-hoc analysis revealed that the hydroslurry only treatment increased the number of competitor species compared to the raking treatment (Tukey HSD, $p<0.05$; Figure 5).

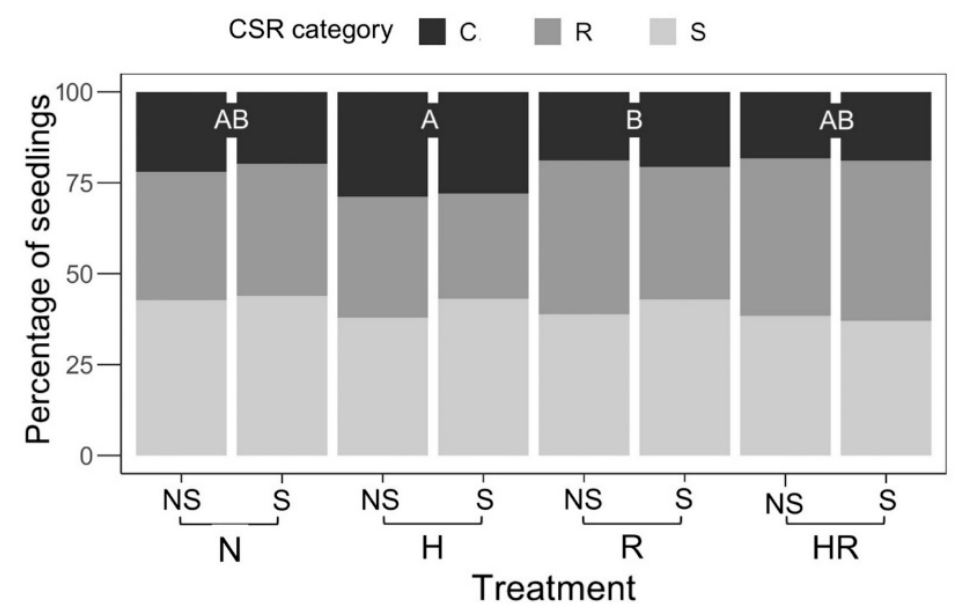

Figure 5. Mean percentage of seedlings that established according to plant adaptive strategies using Grime's CSR categorization (Competitive (C)—dark gray, Ruderal (R)—medium gray, Stress tolerator (S) - light gray). Each bar represents the seeded (NS — not seeded or S—seeded) and site preparation ( $\mathrm{N}$-no preparation, $\mathrm{H}$-hydroslurry, and R-raking). Upper-case letters indicate differences between site preparation treatments for only competitive (C) species (Tukey HSD, $p<0.05$ ).

\section{Discussion}

Seedling establishment at severely disturbed mine sites in semi-arid grasslands can be challenging, particularly when native seed mixes are used. Site preparation and seeding may aid in the establishment of seedlings by reducing the negative environmental conditions that often constrain establishment, like microclimate conditions, poor soil quality, limitations in the number of microclimates suitable for growth and establishment, and propagule pressure [13,16-18].

Raking is a method that is often used to increase the frequency of the occurrence of microclimates that seeds require to germinate [18], and we found that raking assisted in increasing the total number of seedlings that colonized a site, regardless of if the site was seeded or not. Raking may also reduce seed displacement through wind and water movement at post-mining sites, which are typically open and susceptible to erosion $[57,58]$. While we did not observe large amounts of runoff after watering our plots, we may have increased the chance for water erosion and displacement of native seeds. 
However, others suggest that irrigation could promote soil erosion control through indirect effects on soil structure, where increases in water availability enhance aggregate stability [37,59]. We suggest that it is more likely that the low germination rates of the native seeds were the result of seed predation, failure to break dormancy, low seed viability, or low propagule pressure compared to exotic species [60], highlighting the challenges of re-vegetation on altered landscapes in arid environments using native species $[57,58]$.

While total native seedling establishment was low $(7 \%)$, seeding with native species increased richness and native seedling establishment. Raking and seeding also resulted in the greatest species richness compared to all other treatments, suggesting that native seedling establishment is primarily seed-limited but that microclimate is important for some native seeds to germinate [57,61]. Site preparation also impacted the evenness of the system, where the hydroslurry mixture increased evenness and raking decreased evenness relative to each other. We suggest that the hydroslurry mixture likely resulted in alterations to microclimate sites that were suitable for species-specific germination or seedling survival requirements, such as the amount of solar radiation received and water availability $[39,43]$. Further, the components within the hydroseed mixture, such as the binding material or tackifier, may have inhibited the establishment of certain native species, increasing the evenness of the dominant exotic species [25]. On the other hand, raking likely resulted in a more heterogenous soil by creating more microclimate environments for the colonization of more species [17,62]. Overall diversity $\left(\mathrm{H}^{\prime}\right)$ was not impacted by the site preparation treatments, but increased as a result of the seeding treatment, suggesting that diversity was seed-limited either by insufficient sowing of seed and/or because the conditions at the site were not suitable for many native species to break dormancy and germinate $[39,43,60]$.

However, like other studies exploring native seed establishment, the seedlings that became established were almost exclusively exotic species $[20,63,64]$, and seeding only decreased establishment of unseeded species by an average of $6 \%$. The large amount of exotic seedling colonization was likely the result of the topsoil stockpile's seed bank being contaminated with exotic species and/or an influx of seed from adjacent areas that may have been seeded with traditional agronomic species like Melilotus alba, one of the species that contributed the most to community divergence [20,64]. Site preparation did not influence the establishment of exotic species. However, site preparation did alter the composition of species based on plant functional traits and life history strategies, which may be important for determining future steps in successfully revegetating mine sites with native seeds $[7,20,65]$.

Forbs, the most dominant functional group present, decreased, and legumes increased when the hydroslurry treatments were implemented. In this case, legumes appeared to have benefited the most from the conditions that the hydroslurry treatment created. Martínez-Ruiz et al., 2007, found legumes and grasses benefitted from hydroseeding [20], but, in this study, only legumes benefited from hydroseeding but grasses were not impacted by site preparation. The overall high success of forbs compared to grasses and legumes is likely the result of the colonization ability of these species and species-specific requirements for germination and establishment [66]. Kochia scoparia, an exotic forb, dominated the plant communities in this study, which is likely due to the ruderal strategy of this species $[65,66]$. K. scoparia has been found to dominate in the first-year of colonization in another mine restoration study, but this later declined in subsequent years following its initial colonization [66], suggesting that the presence of this species may decrease over time. The other forb that contributed most to community divergence was Salsola tragus, an exotic stress tolerator. While some authors have found poor performance of stress tolerators in semi-natural grasslands [66], others contend that their presence may reflect low soil fertility or a strong degree of habitat specialization of these species $[66,67]$.

While the majority of species in this study were ruderal or stress tolerators, we found that site preparations can impact the abundance of competitive species within the system. Competitors increased when a hydroslurry was used compared to the raking treatment. Like litter, the hydroslurry may have provided additional resources that may have been important for seedling survival allowing 
for greater competitor emergence. In the raking treatment, the decrease in competitors created a positive impact on ruderals and stress tolerators, which may have driven the increase in species richness associated with raking $[57,66]$. In this case, the native species that colonized the site in the highest numbers were either ruderal or stress tolerators. These results further emphasize the idea that restoration of mine sites with native vegetation may provide benefit by improving natural colonization, although this comes at a financial cost and requires more effort managing the site to reduce the success of exotic species $[7,20]$.

\section{Conclusions}

The seedling establishment phase is a critical part of the restoration process, because without native seedling establishment, self-sustaining populations of native species will likely not occur [13-15]. This is particularly true of heavily disturbed areas with seed banks or nearby remnants that are dominated by exotic species. By exploring the colonization of species, we were able to better understand how native species may respond to common restoration methods. While native seedling establishment was low, there are several important aspects to consider when seeding with native species to promote germination and survival. Specifically, native seeds should be sown in large enough numbers to reduce seed limitation and increase establishment. To accomplish this, more research on native seed viability under these harsh conditions may help with successful establishment. Further, species should be carefully selected to ensure the environmental conditions allow for their success, and this may involve a more thorough understanding of how natural colonization strategies can be used to improve the success of native species. Further, raking or tilling can be used to create additional microsites for colonization for ruderal or stress tolerator species to help suppress competitive species. Ultimately, in this experiment, the exotic species were able to capitalize on the disturbance and outcompeted the native species, making it critical to ensure that the topsoil used does not have a seed bank that is overly abundant with exotic species and that wind dispersal of exotic seeds from nearby remnants is minimized.

Supplementary Materials: The following are available online at http://www.mdpi.com/2075-163X/10/4/361/s1, Figure S1: Principal Coordinates Analysis (PCoA) comparing site preparation treatments: C-control (red), $\mathrm{H}$-hydroslurry (green), HR-hydroslurry + raking (blue), and R-Raking (purple). Ellipses represent 95\% confidence intervals, Table S1: Percentage contribution of different plant species contributing $>5 \%$ to community divergence between site preparation treatments based on SIMPER analysis.

Author Contributions: Conceptualization, K.A.B., W.C.G., and L.H.F.; Methodology, K.A.B., W.C.G., and L.H.F.; Software, L.W.P.; Validation, L.W.P.; Formal Analysis, L.W.P.; Investigation, K.A.B., L.W.P., W.C.G., and L.H.F.; Data Curation, K.A.B.; Writing-Original Draft Preparation, K.A.B. and L.W.P.; Writing-Review \& Editing, K.A.B., L.W.P., W.C.G., and L.H.F.; Visualization, L.W.P.; Supervision, W.C.G. and L.H.F.; Funding Acquisition, L.H.F. All authors have read and agreed to the published version of the manuscript.

Funding: This research was funded by the Natural Sciences and Engineering Research Council of Canada (NSERC) Engage Grant in partnership with New Gold New Afton Mine, an NSERC Discovery Grant, and an NSERC Senior Industrial Research Chair in Ecosystem Reclamation to LHF.

Acknowledgments: We thank Scott Davidson, Luke Holdstock, Crystal Simon and Dennis Wilson from New Gold New Afton Mine for access to the site and for their support and input. Dan Denesiuk, Sabina Donnelly, Amanda Schmidt and Larissa Bargoena assisted in field work.

Conflicts of Interest: The authors declare no conflict of interest.

\section{References}

1. Brady, N.C.; Weil, R.R. The Nature and Properties of Soils, 14th ed.; Pearson Education, Inc., Prentice Hall: Upper Saddle River, NJ, USA, 2012; ISBN 978-81-317-8817-2.

2. Johnson, D.B.; Williamson, J.C.; Bailey, A.J. Microbiology of soils at opencast coal sites. I. Short- and long-term transformations in stockpiled soils. J. Soil Sci. 1991, 42, 1-8. [CrossRef]

3. Wanner, M.; Dunger, W. Biological activity of soils from reclaimed open-cast coal mining areas in Upper Lusatia using testate amoebae (protists) as indicators. Ecol. Eng. 2001, 17, 323-330. [CrossRef] 
4. Yurkonis, K.A.; Wilsey, B.J.; Moloney, K.A. Initial species pattern affects invasion resistance in experimental grassland plots. J. Veg. Sci. 2012, 23, 4-12. [CrossRef]

5. Yurkonis, K.A.; Wilsey, B.J.; Moloney, K.A.; Van Der Valk, A.G. The impact of seeding method on diversity and plant distribution in two restored grasslands. Restor. Ecol. 2008, 18, 311-321. [CrossRef]

6. Bohrer, S.L.; Limb, R.F.; Daigh, A.L.; Volk, J.M.; Wick, A.F. Fine and coarse-scale patterns of vegetation diversity on reclaimed surface mine-land over a 40-year chronosequence. Environ. Manag. 2017, 59, 431-439. [CrossRef]

7. Bradshaw, A. Restoration of mined lands-Using natural processes. Ecol. Eng. 1996, 8, 255-269. [CrossRef]

8. Prach, K.; Hobbs, R.J. Spontaneous succession versus technical reclamation in the restoration of disturbed sites. Restor. Ecol. 2008, 16, 363-366. [CrossRef]

9. Carrick, P.J.; Krüger, R. Restoring degraded landscapes in lowland Namaqualand: Lessons from the mining experience and from regional ecological dynamics. J. Arid Environ. 2007, 70, 767-781. [CrossRef]

10. Bochet, E.; Tormo, J.; García-Fayos, P. Native species for roadslope revegetation: Selection, validation, and cost effectiveness. Restor. Ecol. 2010, 18, 656-663. [CrossRef]

11. Christian, J.M.; Wilson, S.D. Long-term ecosystem impacts of an introduced grass in the northern great plains. Ecology 1999, 80, 2397-2407. [CrossRef]

12. Alday, J.G.; Marrs, R.H.; Martínez-Ruiz, C. Vegetation succession on reclaimed coal wastes in Spain: The influence of soil and environmental factors. Appl. Veg. Sci. 2011, 14, 84-94. [CrossRef]

13. Martin, L.M.; Wilsey, B.J. Assessing grassland restoration success: Relative roles of seed additions and native ungulate activities. J. Appl. Ecol. 2006, 43, 1098-1109. [CrossRef]

14. Polley, H.W.; Derner, J.D.; Wilsey, B.J. Patterns of plant species diversity in remnant and restored tallgrass prairies. Restor. Ecol. 2005, 13, 480-487. [CrossRef]

15. Martin, L.M.; Moloney, K.A.; Wilsey, B.J. An assessment of grassland restoration success using species diversity components. J. Appl. Ecol. 2005, 42, 327-336. [CrossRef]

16. Zobel, M.; Otsus, M.; Liira, J.; Moora, M.; Möls, T. Is small-scale species richness limited by seed availability or microsite availability? Ecology 2000, 81, 3274-3282. [CrossRef]

17. Eriksson, O.; Ehrlén, J. Seed and microsite limitation of recruitment in plant populations. Oecologia 1992, 91, 360-364. [CrossRef]

18. Harper, J. Population Biology of Plants; Academic Press: London, UK; New York, NY, USA, 1977.

19. Tognetti, P.M.; Chaneton, E.J. Invasive exotic grasses and seed arrival limit native species establishment in an old-field grassland succession. Biol. Invasions 2012, 14, 2531-2544. [CrossRef]

20. Martínez-Ruiz, C.; Fernández-Santos, B.; Putwain, P.D.; Fernández-Gómez, M.J. Natural and man-induced revegetation on mining wastes: Changes in the floristic composition during early succession. Ecol. Eng. 2007, 30, 286-294. [CrossRef]

21. Emery, S.M.; Gross, K.L. Dominant species identity regulates invasibility of old-field plant communities. Oikos 2006, 115, 549-558. [CrossRef]

22. Pimentel, D.; Zuniga, R.; Morrison, D. Update on the environmental and economic costs associated with alien-invasive species in the United States. Ecol. Econ. 2005, 52, 273-288. [CrossRef]

23. Rowe, H.I. Tricks of the trade: Techniques and opinions from 38 experts in tallgrass prairie restoration. Restor. Ecol. 2010, 18, 253-262. [CrossRef]

24. Bernstein, E.J.; Albano, C.M.; Sisk, T.D.; Crews, T.E.; Rosenstock, S. Establishing cool-season grasses on a degraded arid rangeland of the Colorado Plateau. Restor. Ecol. 2014, 22, 57-64. [CrossRef]

25. Clemente, A.S.; Moedas, A.R.; Oliveira, G.; Martins-Loução, M.A.; Correia, O. Effect of hydroseeding components on the germination of Mediterranean native plant species. J. Arid Environ. 2016, 125, 68-72. [CrossRef]

26. Wilson, S.D.; Gerry, A.K. Strategies for mixed-grass prairie restoration-herbicide, tilling and nitrogen manipulation.pdf. Restor. Ecol. 1995, 3, 290-298. [CrossRef]

27. Montalvo, A.M.; McMillan, P.A.; Allen, E.B. The Relative importance of seeding method, soil ripping, and soil variables on seeding success. Restor. Ecol. 2002, 10, 52-67. [CrossRef]

28. FLH Western Federal Lands Highway Division. An Integrated Approach to Establishing Native Plants; Federal Highway Administration U.S. Department of Transportation: Washington, DC, USA, 2007.

29. Burke, A. Practical measures in arid land restoration after mining-A review for the southern Namib. S. Afr. J. Sci. 2003, 99, 413-417. 
30. Standish, R.J.; Hobbs, R.J. Restoration of OCBILs in south-western Australia: Response to Hopper. Plant Soil 2009, 330, 15-18. [CrossRef]

31. Foster, B.L.; Murphy, C.A.; Keller, K.R.; Aschenbach, T.A.; Questad, E.J.; Kindscher, K. Restoration of prairie community structure and ecosystem function in an abandoned hayfield: A sowing experiment. Restor. Ecol. 2007, 15, 652-661. [CrossRef]

32. Wilson, S.D.; Tilman, D. Plant competition and resource availability in response to disturbance and fertilization. Ecology 1993, 74, 599-611. [CrossRef]

33. Pywell, R.F.; Bullock, J.M.; Hopkins, A.; Walker, K.J.; Tim, H.; Burke, M.J.W.; Peel, S.; Sparks, T.I.M.H. Restoration of species-rich grassland on arable land: Assessing the limiting processes using a multi-site experiment. J. Appl. Ecol. 2002, 39, 294-309. [CrossRef]

34. Kiehl, K.; Kirmer, A.; Donath, T.W.; Rasran, L.; Hölzel, N. Species introduction in restoration projects-Evaluation of different techniques for the establishment of semi-natural grasslands in Central and Northwestern Europe. Basic Appl. Ecol. 2010, 11, 285-299. [CrossRef]

35. Cosgriff, R.; Anderson, V.J.; Monson, S. Restoration of communities dominated by false hellebore. J. Range Manag. 2004, 57, 365-370. [CrossRef]

36. Albaladejo, J.; Castillo, V.; Diaz, E. Soil loss and runoff on semiarid Land as amended. Land Degrad. Dev. 2000, 11, 252-262. [CrossRef]

37. García-Palacios, P.; Soliveres, S.; Maestre, F.T.; Escudero, A.; Castillo-Monroy, A.P.; Valladares, F. Dominant plant species modulate responses to hydroseeding, irrigation and fertilization during the restoration of semiarid motorway slopes. Ecol. Eng. 2010, 36, 1290-1298. [CrossRef]

38. Matesanz, S.; Valladares, F.; Tena, D.; Costa-Tenorio, M.; Bote, D. Early dynamics of plant communities on revegetated motorway slopes from southern Spain: Is hydroseeding always needed? Restor. Ecol. 2006, 14, 297-307. [CrossRef]

39. González-Alday, J.; Marrs, R.H.; Martínez-Ruiz, C. The influence of aspect on the early growth dynamics of hydroseeded species in coal reclamation areas. Appl. Veg. Sci. 2008, 11, 405-412. [CrossRef]

40. Dunifon, S.N.; Evanylo, G.K.; Maguire, R.O.; Goatley, J.M. Soil Nutrient and fescue (festuca spp.) responses to compost and hydroseed on a disturbed roadside. Compos. Sci. Util. 2011, 19, 147-151. [CrossRef]

41. Tormo, J.; Bochet, E.; Garcia-Fayos, P. Roadfill revegetation in semiarid mediterranean environments. Part II: Topsoiling, species selection, and hydroseeding. Restor. Ecol. 2007, 15, 97-102. [CrossRef]

42. Loydi, A.; Eckstein, R.L.; Otte, A.; Donath, T.W. Effects of litter on seedling establishment in natural and semi-natural grasslands: A meta-analysis. J. Ecol. 2013, 101, 454-464. [CrossRef]

43. Oliveira, G.; Nunes, A.; Clemente, A.; Correia, O. Testing germination of species for hydroseeding degraded mediterranean Areas. Restor. Ecol. 2012, 20, 623-630. [CrossRef]

44. Loydi, A.; Donath, T.W.; Otte, A.; Eckstein, R.L. Negative and positive interactions among plants: Effects of competitors and litter on seedling emergence and growth of forest and grassland species. Plant. Biol. 2014, 17, 667-675. [CrossRef] [PubMed]

45. BC Ministry of Forests. The Ecology of the Interior Douglas-fir Zone; British Columbia Ministry of Forests: Victoria, BC, Canada, 2014.

46. Tisdale, E. The Grasslands of the Southern Interior of British Columbia Author. Ecology 1947, 28, 346-382. [CrossRef]

47. Van Ryswyk, A.; McLean, A.; Marchand, L. The climate, native vegetation, and soils of some grasslands at different elevations in British Columbia. Can. J. Plant Sci. 1966, 46, 35-50. [CrossRef]

48. Lee, R.N.; Bradfield, G.E.; Krzic, M.; Newman, R.F.; Cumming, W.F.P. Plant community-Soil relationships in a topographically diverse grassland in southern interior British Columbia, Canada. Botany 2014, 92, 837-845. [CrossRef]

49. Baethke, K.A. Mine Restoration of a Native Grassland Plant Community in the British Columbia Interior: The use of Biochar, Hydroseeding and Raking. Master's Thesis, Thompson Rivers University, Kamloops, BC, Canada, 2015.

50. Fraser, L.H.; Grime, J.P. Interacting effects of herbivory and fertility on a synthesized plant community. J. Ecol. 1999, 87, 514-525. [CrossRef]

51. Oksanen, J.; Blanchet, F.G.; Friendly, M.; Kindt, R.; Legendre, P.; McGlinn, D.; Minchin, P.R.; O’Hara, R.B.; Simpson, G.L.; Solymos, P.; et al. Vegan: Community Ecology Package; World Agroforestry: Nairobi, Kenya, 2016. 
52. Global Invasive Species Database. Available online: http://www.issg.org/database (accessed on 17 April 2020).

53. Grime, J. Competitve exclusion in herbaceous vegetation. Nature 1987, 1, 10037169.

54. Wilson, J.B.; Lee, W.G. C-S-R Triangle theory: Community-level predictions, tests, evaluation of criticisms and relation to other theories. Oikos 2000, 91,77-96. [CrossRef]

55. R Core Team. R: A Language and Environment for Statistical Computing; R Core Team: Copenhagen, Denmark, 2019.

56. Lenth, R. Emmeans: Estimated Marginal Means, aka Least-Squares Means. Available online: https://cran.r-project.org/package=emmeans (accessed on 30 April 2019).

57. Turner, S.R.; Pearce, B.; Rokich, D.P.; Dunn, R.R.; Merritt, D.J.; Majer, J.D.; Dixon, K.W. Influence of polymer seed coatings, soil raking, and time of sowing on seedling performance in post-mining restoration. Restor. Ecol. 2006, 14, 267-277. [CrossRef]

58. Commander, L.E.; Rokich, D.P.; Renton, M.; Dixon, K.W.; Merritt, D.J. Optimising seed broadcasting and greenstock planting for restoration in the Australian arid zone. J. Arid Environ. 2013, 88, 226-235. [CrossRef]

59. Lavee, H.; Sarah, P.; Imeson, A. Aggregate Stability Dynamics as Affected by Soil Temperature and Moisture Regimes; on behalf of the Swedish Society for Anthropology and Geography Stable; Taylor \& Francis Ltd.: Abingdon, UK, 1996; Volume 78, pp. 73-82.

60. Walck, J.L.; Hidayati, S.N.; Dixon, K.W.; Thompson, K.; Poschlod, P. Climate change and plant regeneration from seed. Glob. Chang. Biol. 2011, 17, 2145-2161. [CrossRef]

61. Eriksson, O.; Erikson, A. Effects of arrival order and seed size on germination of grassland plants: Are there assembly rules during recruitment? Ecol. Res. 1998, 13, 229-239. [CrossRef]

62. Turner, C.L.; Knapp, A.K. Responses of a c4 grass and three c 3 forbs to variation in nitrogen and light in tallgrass prairie. Ecology 1996, 77, 1738. [CrossRef]

63. Smith, S.W.; Ross, K.; Karlsson, S.; Bond, B.; Upson, R.; Davey, A. Going native, going local: Revegetating eroded soils on the Falkland Islands using native seeds and farmland waste. Restor. Ecol. 2018, 26, 134-144. [CrossRef]

64. Huxtable, C.H.A.; Koen, T.B.; Waterhouse, D. Establishment of native and exotic grasses on mine overburden and topsoil in the Hunter Valley, New South Wales. Rangel. J. 2005, 27, 73-88. [CrossRef]

65. Pywell, R.F.; Bullock, J.M.; Roy, D.B.; Warman, L.; Walker, K.J.; Rothery, P. Plant traits as predictors of ecological performance. J. Appl. Ecol. 2003, 40, 65-77. [CrossRef]

66. Iverson, L.R.; Wali, M.K. Reclamation of coal mined lands: The role of Kochia scoparia and other pioneers in early succession. Reclam. Reveg. Res. 1982, 1, 123-160.

67. Smith, R.S.; Shiel, R.S.; Millward, D.; Corkhill, P. The interactive effects of management on the productivity and plant community structure of an upland meadow: An 8-year field trial. J. Appl. Ecol. 2000, 37, 1029-1043. [CrossRef]

(C) 2020 by the authors. Licensee MDPI, Basel, Switzerland. This article is an open access article distributed under the terms and conditions of the Creative Commons Attribution (CC BY) license (http://creativecommons.org/licenses/by/4.0/). 